\title{
Multivariate Approach to Identify Potential Varieties of Bread Wheat (Triticum aestivum L.) for Bundelkhand Region of Uttar Pradesh, India
}

\author{
Hitesh Kumar ${ }^{1 *}$, Amit Kumar ${ }^{1 *}$ and Vikas Gupta ${ }^{2}$ \\ ${ }^{1}$ Department of Genetics and Plant Breeding, Banda University of Agriculture and \\ Technology, Banda-210001, India \\ ${ }^{2}$ Division of Crop Improvement, ICAR-Indian Institute of Wheat and Barley Research, \\ Karnal 132001, India \\ *Corresponding author
}

\begin{tabular}{l} 
Ke y w o r d s \\
$\begin{array}{l}\text { Bread wheat, yield } \\
\text { potential, genetic } \\
\text { variability, principal } \\
\text { components }\end{array}$ \\
\hline Article Info \\
\hline $\begin{array}{l}\text { Accepted: } \\
14 \text { May } 2020 \\
\text { Available Online: } \\
10 \text { June } 2020\end{array}$ \\
\hline
\end{tabular}

\section{A B S T R A C T}

The study aims to evaluate the yield potential of 60 bread wheat varieties along with three mega-varieties. The experiment was laid down in an augmented design at Banda Agriculture University, Banda, U.P. during rabi 2017-18. The data was recorded on days to $75 \%$ heading, days to maturity, plant height and grain yield. The recorded observation were analysed to identify the best performing varieties. Analysis of variance exhibited highly significant differences $(\mathrm{P}<0.001)$ among the test varieties for all traits except days to maturity indicating the presence of variability in the experimental material. The highest variance was found for grain yield followed by plant height and $75 \%$ flowering while, it was recorded lowest for days to maturity. The less significant difference were found for days to maturity among all lines. The varieties HI 1544 (5773 kg/ha), PBW 621(5773 kg/ha), MP $1203(5583 \mathrm{~kg} / \mathrm{ha})$, UP $2526(5545 \mathrm{~kg} / \mathrm{ha})$ and UP $2554(5545 \mathrm{~kg} / \mathrm{ha})$ recorded highest grain yield. UP 2382 was early matured variety (109 days) among all tested varieties. The PCA and biplot analysis was also undertaken to understand the comparative performance of genotypes in terms of their yield and contributing traits. The first two PCs contributed $79.37 \%$ of total variance with 42.03 (PC1) and 37.35 (PC2) eigenvalues. The PC1 and PC2 were significantly influenced by days to $75 \%$ heading and seed yield.

\section{Introduction}

Wheat is the second most important staple food crop after rice, belongs to family gramineae. It is often considered as a major source of energy and also contains valuable amounts of other important nutrients including fiber, protein. The global production of wheat is 766.4 million tons during 2018-19, with increase of $4.8 \%$ (34.8 million tonnes) from the previous year ( http://www.fao.org/worldfoodsituation/csdb/e $\mathrm{n} /)$.

In India, the production is 101.20 million tons from 29.55 million ha (13.43\% of global area) and highest productivity is $3424 \mathrm{~kg} / \mathrm{ha}$ during 2018-19 (ICAR-IIWBR Annual Report 2018- 
19). Wheat contributes 33 percent of total food grain under cereals in the country from 28 percent area (Rangare et al., 2010). The major wheat producing states are Uttar Pradesh, Punjab, Haryana, Madhya Pradesh, Rajasthan, Bihar, Maharashtra, Gujarat, Karnataka, West Bengal, Uttarakhand, Himachal Pradesh and Jammu \& Kashmir. Uttar Pradesh stands first in terms of area 96.37 lakh ha $(33.15 \%$ of the total area) and contributes about $34.53 \%$ share in total production of the country (DWR, Perspective Plan Vision 2025).

However, in terms of productivity, Punjab and Haryana were on top with 5077 and 4643 $\mathrm{kg} / \mathrm{ha}$ respectively, whereas the productivity of Uttar Pradesh was $3269 \mathrm{~kg} / \mathrm{ha}$ compared to the national average of $3424 \mathrm{~kg} / \mathrm{ha}$ (Singh et al., 2019).

Wheat is also one of the most important cereal crops in the Bundelkhand region occupying an area of 8.32 lakh hectares with a production and productivity of 23.35 lakh tonnes and $2776 \mathrm{~kg} / \mathrm{ha}$, respectively (Directorate of Economics and Statistics, Gov. of Uttar Pradesh 2018-19).

The productivity of Bundelkhand region is lower as compared to the state average productivity $(3626 \mathrm{Kg} / \mathrm{ha})$. The central and eastern regions of Bundelkhand had a wider gap between potential (40-50 q/ ha) and realized yields ( $<30 \mathrm{q} / \mathrm{ha})$.

The major constraints for low productivity of the region as well as of the state are cultivation of old, low yielding, susceptible varieties, poor quality seed, untimely availability of quality seed, late sowing and also poor mechanization badly affects the wheat cultivation in the state. Due to lack of awareness among the farmers about improved agricultural technology, adoption rate of new technologies is very low in the region.
In view of the above reasons the low productivity of wheat can be improved by replacement of old varieties with improved wheat varieties recommended for this region. The newly released high yielding varieties can play a major role in improving the productivity as well as expanding the area in the target region. Adoption of improved varieties itself can enhance productivity by 20 to $25 \%$. (Rain fed authority of India 2011). Grain yield being a polygenic trait fluctuates widely as a result of genotype $\mathrm{x}$ environment interaction (Akram et al., 2008).

The knowledge of variability helps plant breeder in predicting the behavior of the succeeding generation and making desirable selections in a diverse set of germplasm lines. The estimation of variability, understanding the genetic distance between parents which are directly proportional to the extent of heterosis. The variability is essential for genetic improvement of any crop (Ramya and Senthil Kumar, 2009). Because, the yield is not only affected directly by environmental components but also affected indirectly by other yield components in negative or positive manner.

For increasing wheat production prime importance should be given to widely adapted high yielding varieteis. Generating information about the yield potential and genetic variability among yield contributing factors is the key task in genetic improvement of any crop plant (Naik et al., 2015).

The most challenging task for wheat breeders is not only to increase yield potentaial but also enriching the trait diversity in the populations with which breeders work. Keeping in view the above facts the present experiment was undertaken to evaluate the performance of released varieties with respect to grain yield and also to identify material suitable for Bundelkhand region. 


\section{Materials and Methods}

\section{Plant materials}

A set of 63 bread wheat varieties comprising recently released varieties, local and obsolete cultivars were evaluated with three checks Lok-1, HD 2967 and WH 142 during rabi 2017-18 at experimental farm of Banda University of Agriculture and Technology, Banda, UP. The Lok-1 and WH 147 are heat tolerant and are widely preferred varieties for cultivation in the region. HD 2967, a ruling variety recommended for cultivation in North Western and Eastern Plane Zones (NWPZ \& NEPZ) of the country also the choice of the farmers in this region. The weather conditions of this region are warm and dry which force wheat crop to mature early. The experiment was laid out in an augmented design with repeated checks in each block (Federer, 1956). The total 10 test varieties were planted in a block along with three randomly repeated checks to control local error thus making total six blocks (Stringer and Cullis, 2002). Each test variety was planted in a 6 rows plot of 4 $\mathrm{m}$ length with a spacing of $18.5 \mathrm{~cm}$ between rows. Recommended package of practices were followed to raise healthy wheat crop during season.

\section{Measured traits}

The varieties were evaluated for agromorphological traits namely; days to $75 \%$ heading (DTH), days to maturity (DTM), plant height $(\mathrm{PH})$ and grain yield per ha (GY) for all the test varieties and checks. For measuring days to $75 \%$ heading (days counted from date of sowing to the days of heading in $75 \%$ plants completed); for days to maturity(days counted from date of sowing to the days of physiological maturity completed); for plant height (height was taken from base of soil surface to terminal of spike excluding awns on five randomly selected plants from each plot); grain yield per plot were taken from net plot six-rows of $4 \mathrm{~m}$ length for each genotype. The data thus recorded were subjected to statistical analysis.

\section{Statistical analysis}

The data of test varieties was analyzed as per the statistical procedure suggested by Johnson et al., (1955), along with repeated checks to estimate adjusted mean of each entry and analysis of variance (ANOVA) with the help of Statistical software GenStat 14th edition (Payne et al., 2011).The recorded observations were analyzed identify the best performing variety in the region and to estimate the genetic parameters with SPAD software and SPAR 2.0.

\section{Results and Discussion}

The analysis of variance (ANOVA) for each character indicated significant differences except days to maturity among test varieties (Table 1). The contrast analyses revealed among test lines are significant for all traits except DTM while among check differences are significant. Similarly, the test vs check was also non-significant for DTH, which indicating that the test varieties were not different from check for traits under studies except DTH. The less significant variance was found for DTM among all lines. This result revealed the greater genetic variability in genotypes for all traits except DTM which will be used for selection of these traits. The adjusted variety and check means for each trait is presented in Table 2 .

\section{Varietal performance with respect to measured traits}

The trait mean values for DTH (81 days), PH (95 am), DTM (115 days) and GY (4328 $\mathrm{kg} / \mathrm{ha}$ ) are presented in Table 3. The highest co-efficient of variation (CV) was found for 
GY $(21 \%)$ followed by DTH $(6.45 \%)$ and PH $(6.038 \%)$ while, DTM $(2.41 \%)$ had lowest C.V. value. The box plots depicting variability for all the traits are shown in Fig-1. The DTH among varieties ranged from 67 days (GW 173) to 90 days (Surya Jayoti). Rapid plant development in early vegetative growth stage with early flowering is the most important trait to avoid terminal heat stress (Shavrukov et al., 2017).

Basic statistics data of DTM revealed that maturity duration ranged from 109 days (UP2382) to 121 days (HI 8498). Variety C 306 took 120 days from seed to seed. The KW-51 variety was noted dwarf with $78 \mathrm{~cm}$ height among taken lines followed by check variety Lok 1with $83 \mathrm{~cm}$.

The variety BHU 409 recorded highest plant height of $103 \mathrm{~cm}$. The varieties HI $1544(5773$ $\mathrm{kg} / \mathrm{ha})$, PBW 621(5773 kg/ha), MP 1203 (5583 kg/ha), UP 2526 (5545 kg/ha) and UP 2554 (5545 kg/ha) had highest GY (Table 3).

Yield is the most important among all components traits of a variety which largely depends on four factors such as spike length, spikelets per spike, grains per spike and seed index (Nizamani et al., 2020). The varieties Super 231 (2567 kg/ha), KW-51(2376 kg/ha) were poor performer at this site. The three varieties i.e. Kundan, WR544 and PBW550 showed high yield performance in the Indogangetic plains of India and was also reported by Pandey et al., 2019.

\section{Cluster and principal component analysis}

PCA and cluster analysis allowed a natural grouping of the wheat genotypes. The cluster analysis was performed using euclidean distance matrix which sequestrate 63 genotypes into four clusters (Fig.2, Table 4). Cluster I consisted of 8 genotypes whereas Cluster II consisted of 17 genotypes, cluster
III of 20 genotypes and cluster IV with 18 genotypes. Similarly, thirty two genotypes were clustered into 6 clusters reported by Santosh et al., 2019.

The cophenetic correlation coefficient of the clusters is $r=0.578$, which indicate agreement of graphical representation of the distance and correlation matrix, supporting the visual inference in the form of dendrogram (Fig. 2). Evaluation of genetic diversity can be useful for the selection of the most efficient genotypes.

The principal component analysis (PCA) transforms the large complex data into smaller correlated number of variables (PCs) with contribution to the total variance. The maximum percent contribution towards total divergence was also reported from grain yield per plot followed by canopy temperature, biological yield per plant and minimum by harvest index (Santosh et al., 2019). These variables are less than or equal to original variables. In the present study, the recorded data for four traits was subjected to principal component analysis to understand the performance of genotypes in terms of their yield and contributed traits.

The analysis had transformed whole data into four PCs, which indicate that the first two PCs had the major proportion of the total variance. The first two PCs, eigen values $>1$ accounted for $79.38 \%$ of total variance for grain yield. The PC1 accounted $42.03 \%$ variation into grain yield followed by PC2 $(37.35 \%)$, PC3 f (12.72\%) and PC4 (7.91\%) variance (Table 5). Saba et al., 2017 also transformed recorded data into eight $\mathrm{PCs}$, in which, first three components accounted $68.8 \%$ of the total variation. The first two principal components contributing more than half of the variance were plotted to observe relationships between the grouping of varieties (Fig. 3a). 
Table.1 ANOVA result of grain yield and yield components in 63 bread wheat lines

\begin{tabular}{|l|c|c|c|c|c|}
\hline Sources & Df & DTH $_{\text {Mss }}$ & PH $_{\text {Mss }}$ & DTM $_{\text {Mss }}$ & GY $_{\text {Mss }}$ \\
\hline Lines & 62 & $29.27^{* * *}$ & $39.78^{* * *}$ & 8.59 & $512624.43^{* *}$ \\
\hline Block & 5 & 1.97 & $18.49^{*}$ & 5.20 & 35927.29 \\
\hline Error & 10 & 3.03 & 3.72 & 6.37 & 93966.32 \\
\hline Contrast analysis & & & & & \\
\hline Among check & 2 & $260.17^{* * *}$ & $100.06^{* * *}$ & $103.17 * * *$ & $425043.57^{*}$ \\
\hline Among test lines & 59 & $21.94^{* * *}$ & $22.02^{* *}$ & 4.79 & $490821.83^{* *}$ \\
\hline Test lines vs checks & 1 & 0.02 & $967.43^{* * *}$ & $43.21^{*}$ & $1974117.48^{* *}$ \\
\hline
\end{tabular}

Mss Mean sum of squire, * Indicates significance at $\mathrm{P}=.05$, * Indicates significance at $\mathrm{P}=.01$, *** Indicates

significance at $\mathrm{P}=.001$, Days to $75 \%$ heading (DTH), Plant height (PH), Days to maturity (DTM), Seed Yield $\mathrm{Kg} / \mathrm{ha}$ $(\mathrm{GY})$

Table.2 Means of agro-morphological traits on evaluated varieties

\begin{tabular}{|c|c|c|c|c|c|c|c|c|c|c|c|}
\hline $\begin{array}{c}\text { S. } \\
\text { No. }\end{array}$ & Variety & DTF & PH & DTM & GY & S. No. & Variety & DTF & PH & DTM & SY \\
\hline 1 & Raj 3765 & 75 & 89 & 112 & 3672 & 34 & HI 8498 & 87 & 89 & 121 & 4059 \\
\hline 2 & Super $20-51$ & 78 & 96 & 116 & 3291 & 35 & MP 1203 & 88 & 94 & 118 & 5583 \\
\hline 3 & G K Pradhan & 76 & 93 & 113 & 3252 & 36 & MP 4110 & 86 & 89 & 115 & 4287 \\
\hline 4 & PBW 234 & 78 & 88 & 117 & 3729 & 37 & BHU 408 & 86 & 99 & 116 & 4973 \\
\hline 5 & Ajeet-349 & 78 & 83 & 115 & 2795 & 38 & UP 2628 & 86 & 99 & 117 & 5164 \\
\hline 6 & Kaweri KW-11 & 83 & 93 & 115 & 3043 & 39 & PBW 621 & 87 & 99 & 118 & 5754 \\
\hline 7 & Super 231 & 82 & 88 & 118 & 2567 & 40 & DBW 17 & 89 & 89 & 118 & 4954 \\
\hline 8 & KW-51 & 78 & 78 & 115 & 2376 & 41 & UP 2565 & 80 & 97 & 115 & 4415 \\
\hline 9 & MW-72 & 78 & 96 & 114 & 2910 & 42 & PBW 343 & 85 & 97 & 117 & 3520 \\
\hline 10 & Ajeet 102 & 69 & 88 & 113 & 2681 & 43 & WR 544 & 72 & 87 & 114 & 3386 \\
\hline 11 & Nath Wonder & 84 & 91 & 114 & 3355 & 44 & PBW 16 & 86 & 100 & 117 & 5539 \\
\hline 12 & Surya Jayoti & 90 & 101 & 115 & 4669 & 45 & UP 2425 & 82 & 100 & 116 & 4243 \\
\hline 13 & Ankur Kedar & 81 & 99 & 113 & 5050 & 46 & JK Vijay & 87 & 102 & 115 & 5101 \\
\hline 14 & UdaySCW 105 & 80 & 101 & 113 & 4840 & 47 & VL 892 & 80 & 102 & 113 & 4815 \\
\hline 15 & NL 266 & 76 & 96 & 112 & 2878 & 48 & HD 2864 & 81 & 102 & 114 & 5253 \\
\hline 16 & Sri Ram 152 & 81 & 101 & 114 & 5221 & 49 & PBW 550 & 85 & 100 & 115 & 4643 \\
\hline 17 & Balram 011 & 74 & 101 & 112 & 3069 & 50 & BHU 5 & 87 & 97 & 119 & 4053 \\
\hline 18 & Super 303 & 68 & 91 & 118 & 3736 & 51 & UP 2338 & 75 & 93 & 116 & 4402 \\
\hline 19 & BHU-1 & 78 & 101 & 113 & 4116 & 52 & PBW 226 & 82 & 101 & 115 & 4555 \\
\hline 20 & AnkurManglesh & 77 & 99 & 113 & 5259 & 53 & BHU 409 & 88 & 103 & 117 & 4878 \\
\hline 21 & Mahyco Gold & 81 & 97 & 111 & 5449 & 54 & GW 173 & 67 & 103 & 110 & 3793 \\
\hline 22 & UP 2526 & 78 & 97 & 112 & 5545 & 55 & PBW 373 & 86 & 98 & 116 & 3697 \\
\hline 23 & HI 1544 & 73 & 97 & 110 & 5773 & 56 & HD 3086 & 82 & 88 & 118 & 2783 \\
\hline 24 & BHU-6 & 78 & 97 & 111 & 4764 & 57 & RWV 4106 & 82 & 88 & 119 & 3736 \\
\hline 25 & Sonalika C/S & 81 & 97 & 112 & 5240 & 58 & HD 3117 & 84 & 93 & 119 & 3526 \\
\hline 26 & HD 2329 & 84 & 97 & 112 & 4745 & 59 & HD CSW 18 & 82 & 103 & 117 & 4288 \\
\hline 27 & HD 2733 & 85 & 97 & 115 & 4668 & 60 & HD 3171 & 82 & 101 & 117 & 4936 \\
\hline 28 & UP 2554 & 84 & 97 & 115 & 5545 & 61 & Lok-1 (Ch) & 73 & 83 & 112 & 4857 \\
\hline 29 & BHU 3 & 82 & 97 & 110 & 4649 & 62 & HD $2967(\mathrm{Ch})$ & 86 & 91 & 120 & 4825 \\
\hline 30 & UP 2382 & 80 & 97 & 109 & 4516 & 63 & WH $142(\mathrm{Ch})$ & 84 & 87 & 118 & 4381 \\
\hline 31 & PBW 154 & 78 & 89 & 113 & 4783 & & & & & & \\
\hline 32 & UP 2572 & 78 & 94 & 117 & 5373 & & & & & & \\
\hline 33 & C 306 & 88 & 89 & 120 & 4706 & & & & & & \\
\hline
\end{tabular}


Table.3 Mean, range, reduction percent, CV for grain yield and yield components in 63 bread wheat released varieties

\begin{tabular}{|l|c|c|c|c|c|c|c|c|}
\hline Variable & Min & Max & Mean & Range & Variance & StdDev & SEMean & CV \\
\hline DTH & 67.00 & 90.00 & 80.97 & 23.00 & 27.26 & 5.22 & 0.66 & 6.45 \\
\hline DTM & 109.00 & 121.00 & 114.98 & 12.00 & 7.69 & 2.77 & 0.35 & 2.41 \\
\hline PH & 78.110 & 103.110 & 95.072 & 25.000 & 32.951 & 5.740 & 0.723 & 6.038 \\
\hline GY & 2376 & 5773 & 4328 & 3397 & 820247 & 906 & 114 & 21 \\
\hline
\end{tabular}

Table.4 Four cluster grouping wheat genotypes based on quantitative traits

\begin{tabular}{|c|c|l|}
\hline Cluster No & Cluster Size & \multicolumn{1}{|c|}{ varieties in cluster } \\
\hline $\mathbf{1}$ & 8 & Raj 3765 Ajeet-349 KW-51 Ajeet 102 Super 303 PBW 154 WR 544 Lok-1 (Ch) \\
\hline $\mathbf{2}$ & 17 & $\begin{array}{l}\text { Super 20-51 PBW 234 Kaweri KW -11 Super 231 Nath Wonder C 306 HI 8498 MP } \\
\text { 4110 DBW 17 PBW 343 BHU 5 PBW 373 HD 3086 RWV 4106 HD 3117 HD 2967 } \\
\text { (Ch) WH 142(Ch) }\end{array}$ \\
\hline $\mathbf{3}$ & 20 & $\begin{array}{l}\text { G K Pradhan MW-72 Ankur Kedar Uday SCW 105 NL 266 Sri Ram 152 Balram 011 } \\
\text { BHU-1 Ankur Manglesh Mahyco Gold UP 2526 HI 1544 BHU-6 Sonalika C/S HD } \\
\text { 2329 BHU 3 UP 2382 VL 892 HD 2864 GW 173 }\end{array}$ \\
\hline $\mathbf{4}$ & 18 & $\begin{array}{l}\text { Surya Jayoti HD 2733 UP 2554 UP 2572 MP 1203 BHU 408 UP 2628 PBW 621 UP } \\
\text { 2565 PBW 16 UP 2425 JK Vijay PBW 550 UP 2338 PBW 226 BHU 409 HD CSW 18 } \\
\text { HD 3171 }\end{array}$ \\
\hline
\end{tabular}

Table.5 Principal Component analysis of 63 wheat varieties

\begin{tabular}{|l|l|l|l|l|r|r|r|r|}
\hline $\begin{array}{l}\text { Principle } \\
\text { component }\end{array}$ & \multicolumn{4}{|c}{ Statistics of PC } & \multicolumn{3}{c|}{ Eigenvectors of the four variables } \\
\cline { 2 - 10 } & $\begin{array}{l}\text { Standard } \\
\text { deviation }\end{array}$ & $\begin{array}{l}\text { Proportion of } \\
\text { Variance }\end{array}$ & $\begin{array}{l}\text { Cumulative } \\
\text { Proportion }\end{array}$ & $\begin{array}{l}\text { Eigen } \\
\text { Values }\end{array}$ & DTF & PH & \multicolumn{1}{|l}{ DTM } & SY \\
\hline PC1 & 1.2965 & 0.4203 & 0.4203 & 1.681 & 0.5971 & 0.484 & 0.2281 & 0.5977 \\
\hline PC2 & 1.2222 & 0.3735 & 0.7937 & 1.4939 & -0.4077 & 0.4795 & -0.7195 & 0.2935 \\
\hline PC3 & 0.7134 & 0.1272 & 0.9209 & 0.5089 & 0.0892 & 0.6959 & 0.1272 & -0.7011 \\
\hline PC4 & 0.5623 & 0.0791 & 1 & 0.3162 & 0.6851 & -0.2271 & -0.6435 & -0.2549 \\
\hline
\end{tabular}
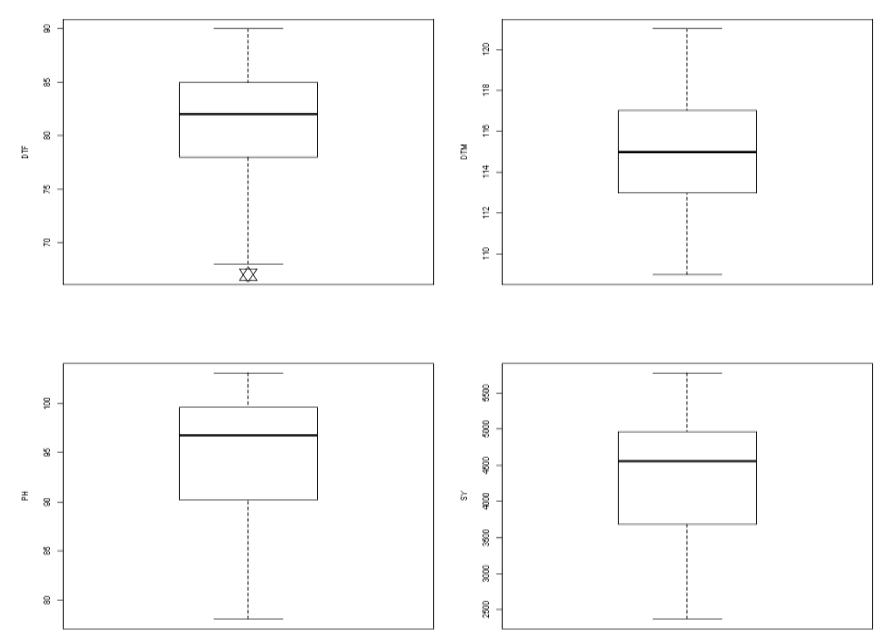

Fig.1 Box plots depicting variation for days to $75 \%$ heading (DTH), plant height (PH), days to maturity (DTM), seed yield $\mathrm{Kg} / \mathrm{ha}(\mathrm{GY})$ 


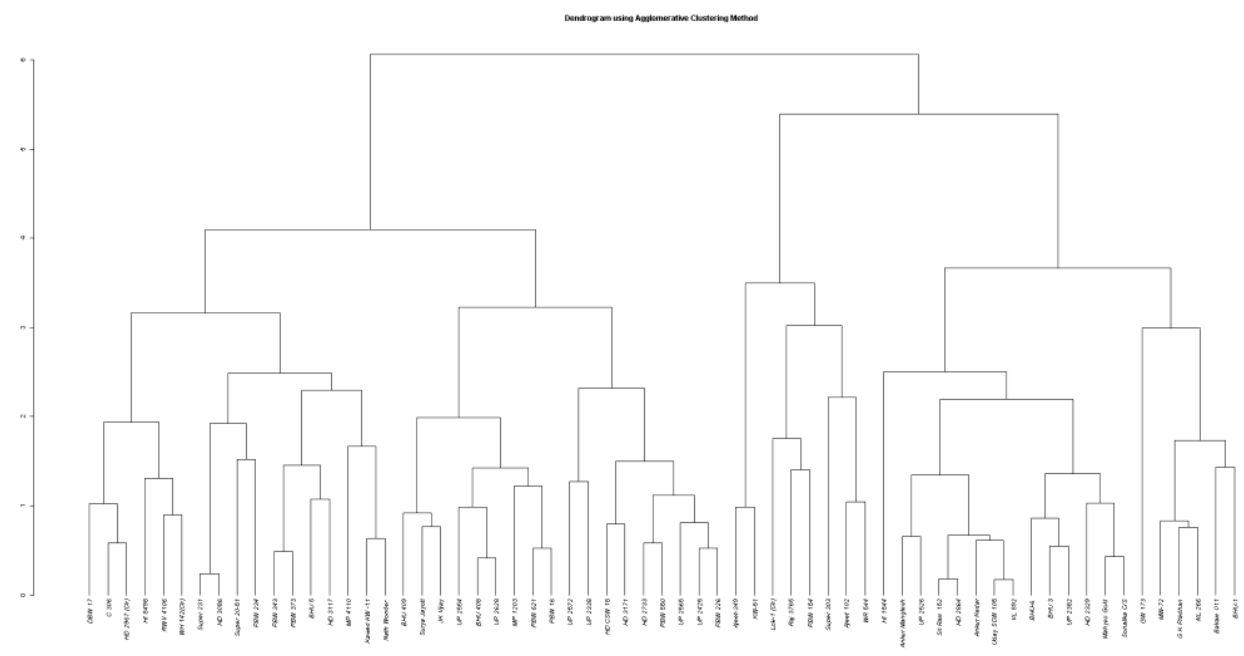

Fig.2 Cluster diagram of 63 wheat genotypes based on morphoagronomic traits

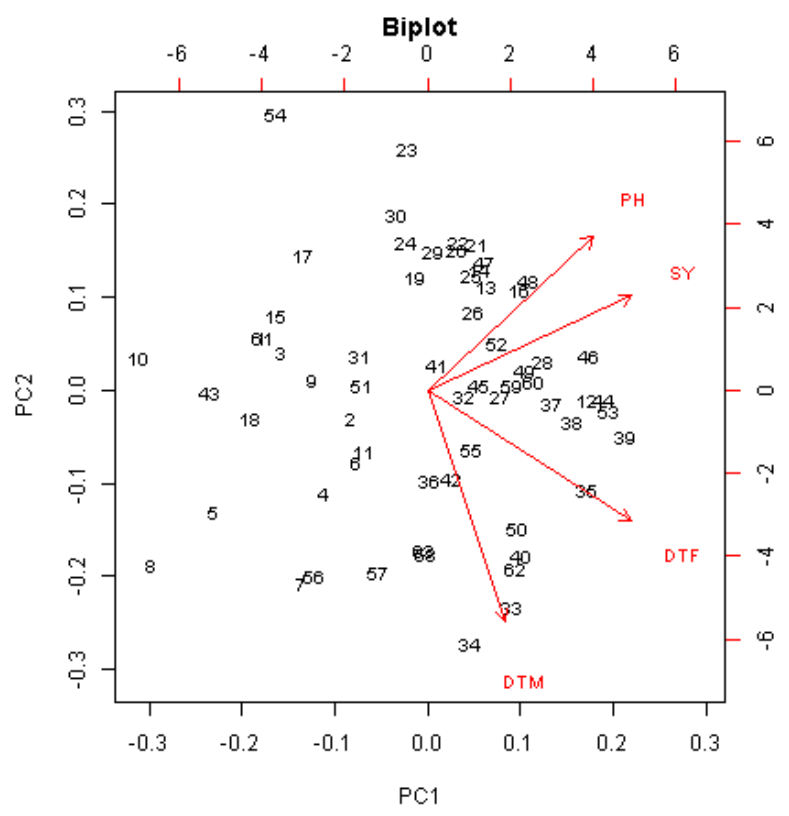

Fig.3 Biplot representing association of traits with grain yield

The PC1 was positively influenced by days to $75 \%$ heading (0.5971), plant height (0.484) and seed yield per ha (0.5977) while, PC2 by plant height $(0.4795)$, and seed yield per ha (0.2935). PC3 was influenced positively by DTH, PH and DTM while seed yield per ha had negative influence (0.7011). The PC4 was negatively influenced by all quantitative traits except DTF (Table 5). A biplot configuration of 63 wheat genotypes has been presented in Fig. 3b represented association among traits which showed that plant height and days to $75 \%$ heading had positive influences on seed yield whereas, days to maturity showed negative influences.

In the present study 63 wheat varieties were evaluated for yield and related components traits. Significant genetic variations were observed among the wheat varieties for all the 
studied parameters except DTM. HI 1544 (5773 kg/ha), PBW 621(5773 kg/ha), MP 1203 (5583 kg/ha), UP 2526 (5545 kg/ha) and UP $2554 \quad(5545 \mathrm{~kg} / \mathrm{ha})$ had highest productivity as compared to checks. As these varieties excelled in performance for yield and yield components, thus, could be recognized for commercial cultivation in Bundelkhand region. UP 2382 was identified to be an early maturing variety among all tested varieties could be used as parent in hybridization to create variability for early maturing breeding material for this region. Based on these key traits, the genetic potential of these wheat varieties can also be exploited in wheat breeding programs.

\section{Author contributions}

Conceptualization, HK, Data curation, and AK, Methodology, HK and AK, Software, $\mathrm{VG}$, Writing-original draft, $\mathrm{HK}$, and $\mathrm{AK}$, Writing-review \& editing, VG. All authors have read and agreed to the published version of the manuscript.

\section{Acknowledgments}

The authors acknowledge the financial support given by BUAT, Banda for providing experimental farm and facility.

\section{References}

Akram Z., Ajmal S. U. and Munir M., 2008. Estimation of correlation coefficient among some yield parameters of wheat underrainfed conditions. Pakistan Journal of Botany 40(4): 1777-1781.

Dewey, D.R. and Lu, K., 1959. A Correlation and Path-Coefficient Analysis of Components of Crested Wheatgrass Seed Production 1. Agronomy journal, 51(9), pp.515-518.

Naik, V.R., Biradar, S.S., Yadawad, A., Desai, S.A. and Veeresha, B.A., 2015.
Study of genetic variability parameters in bread wheat (Triticum aestivum L.) genotypes. Res. J. Agric. Sci, 6(1), pp.123-125.

Nizamani, M.M., Nizamani, F.G., Rind, R.A., Khokhar, A.A., Mehmood, A. and Nizamani, M., 2019. Heritability and genetic variability estimates in F3 populations of bread wheat (Triticum aestivum L.). Pure and Applied Biology. Vol. 9, Issue 1, pp352-368.

Pandey, A.K., Majumder, B., Keski-Saari, S., Kontunen-Soppela, S., Pandey, V. and Oksanen, E., 2019. High Variation in resource allocation strategies among 11 Indian wheat (Triticum aestivum) cultivars growing in high ozone environment. Climate, 7(2), p.23.

Ramya, K. and Senthilkumar, N., 2009. Genetic divergence, correlation and path analysis in okra (Abelmoschus esculentus L. Moench). Madras Agricultural Journal, 96(7-12), pp.296-299.

Rangare, N.R., Krupakar, A., Kumar, A. and Singh, S., 2010. Character association and component analysis in wheat (Triticum aestivum L.). Electronic Journal of Plant Breeding, 1(3), pp.231-238.

Saba, I., Sofi, P.A., Zeerak, N.A., Mir, R.R. and Gull, M., 2017. Using augmented design for evaluation of common bean (Phaseolus vulgaris $\quad$ L.) Germplasm. International Journal of Current Microbiology and Applied Science, 6(7), pp.246-254.

Santosh, J.P., Singh, A. and Gahatyari, N.C., 2019. Genetic Diversity Analysis in Bread Wheat (Triticum aestivum L. em. Thell.) for Yield and Physiological Traits. Int. J. Curr. Microbiol. App. Sci, 8(2), pp.30593068.

Shavrukov, Y., Kurishbayev, A., Jatayev, S., Shvidchenko, V., Zotova, L., 
Koekemoer, F., de Groot, S., Soole, K. and Langridge, P., 2017. Early Flowering as a Drought Escape Mechanism in Plants: How Can It Aid Wheat Production? Front. Plant Sci. 8:1950. doi: 10.3389/fpls.2017.01950

Singh, G.P., Sendhil, R. and K, Gopalareddy, 2019. Maximization of National Wheat Productivity: Challenges and
Opportunities. In: Current Trends in Wheat and Barley Research and Development, Ed.: Sai Prasad SV, Mishra AN and GP Singh. ICN: 218/2019.

Singh., 1990. Correlation and path analysis in segregating generations of Chickpea. Indian Journal of Pulses research. 12(2):187-191.

\section{How to cite this article:}

Hitesh Kumar, Amit Kumar and Vikas Gupta. 2020. Multivariate Approach to Identify Potential Varieties of Bread Wheat (Triticum aestivum L.) for Bundelkhand Region of Uttar Pradesh, India. Int.J.Curr.Microbiol.App.Sci. 9(06): 254-262. doi: https://doi.org/10.20546/ijcmas.2020.906.032 